\title{
A Blind Normal Fault beneath the Taipei Basin in Northern Taiwan
}

\author{
Kou-Cheng Chen ${ }^{1, *}$, Bor-Shouh Huang ${ }^{1}$, Win-Gee Huang ${ }^{1}$, Jeen-Hwa Wang ${ }^{1}$, Kwang-Hee Kim ${ }^{2}$, \\ Shiann-Jong Lee ${ }^{1}$, Ya-Chuan Lai ${ }^{3}$, Shuhjong Tsao ${ }^{4}$, and Chi-Hsuan Chen ${ }^{4}$ \\ ${ }^{1}$ Institute of Earth Sciences, Academia Sinica, Taipei, Taiwan, ROC \\ ${ }^{2}$ Korea Ocean Research and Development Institute, Ansan, Korea \\ ${ }^{3}$ Institute of Geophysics, National Central University, Jhongli, Taiwan, ROC \\ ${ }^{4}$ Central Geological Survey, Ministry of Economic Affairs, Taipei, Taiwan, ROC \\ Received 9 April 2008, accepted 25 January 2010
}

\begin{abstract}
The Taipei basin, historically low in seismicity, is located in northern Taiwan. A dense broadband seismic array was deployed in the basin in June 2004 to monitor seismic activity. During the period of operation, three felt earthquakes occurred near the eastern part of the Taipei basin, about $3 \mathrm{~km}$ to the south of Taipei 101 then the tallest building in the world. Relocated earthquakes show a southeast-dipping distribution of hypocenters beneath the Taipei basin. The seismicity pattern and focal mechanisms of the three felt events suggest the existence of a blind normal fault whose surface projection is along the river channel in the middle of the basin.
\end{abstract}

Key words: Taipei basin, Seismicity, Blind normal fault

Citation: Chen, K. C., B. S. Huang, W. G. Huang, J. H. Wang, K. H. Kim, S. J. Lee, Y. C. Lai, S. Tsao, and C. H. Chen, 2010: A blind normal fault beneath the Taipei basin in northern Taiwan. Terr. Atmos. Ocean. Sci., 21, 495-502, doi: 10.3319/TAO.2010.01.25.01(TH)

\section{INTRODUCTION}

Taiwan is situated along the collision boundary between the Philippine Sea plate and the Eurasian plate (Tsai et al. 1977; Wu 1978; Lin 2002). The former is moving northwestward with a speed of about $7 \mathrm{~cm} \mathrm{yr}^{-1}$ (Seno 1977). The Philippine Sea plate has subducted underneath the Eurasian plate in northern Taiwan (Fig. 1). This collision causes high seismicity in the Taiwan region (e.g., Wang 1998). The Taipei Metropolitan Area (TMA), the political, economic, and cultural center of Taiwan, including the City of Taipei and several satellite cities lies within the Taipei basin and demands serious attention to seismic risk mitigation. In the past two decades, many buildings in the TMA have collapsed or were damaged as a result of numerous distant earthquakes, such as the Hualien offshore earthquakes of 20 May and 14 November 1986 (Chen and Wang 1988), the Chi-Chi earthquake of 21 September 1999 (Shin and Teng 2001), and the Hualien offshore earthquake of 31 March 2002 (Chen 2003). In addition to the damages caused by distant events, in 1694 and 1909, TMA was also damaged

\footnotetext{
* Corresponding author

E-mail: chenkc@earth.sinica.edu.tw
}

by earthquakes underneath the basin (Hsu 1961, 1983). Hence, the studies of seismicity and delineation of faults as well as their geometry in this area are important to assess earthquake hazards.

From the Pliocene to the Pleistocene, three main reverse faults developed along the western boundary of the Western Foothills in the Taipei basin (Ho 1986). From NW to SE, the three faults are: the Hsinchuang fault, the Kangjiao fault, and the Taipei fault, all trending in the NE-SW direction (Fig. 1). A segment of the Hsinchuang fault has been re-activated as a normal fault and is called the Shanchiao fault (Fig. 1). Tan (1939) proposed that the Taipei basin was formed by the downfall of a hanging wall along the Shanchiao fault. From the epicentral distributions, several authors (Tsai et al. 1973; Wang et al. 1983, 2006; Wang 1988; Chen and Yeh 1991; Chen et al. 1995; Chen 2005; Kim et al. 2005a; Konstantinou et al. 2007) show lower seismicity in the Taipei basin than other areas in northern Taiwan and a low correlation between seismicity and recognized faults. A dense broadband seismic array has been deployed in the Taipei basin since June 2004 to monitor seismic activity and to study the focal mechanisms associated with the faults. During the period of operation, three 

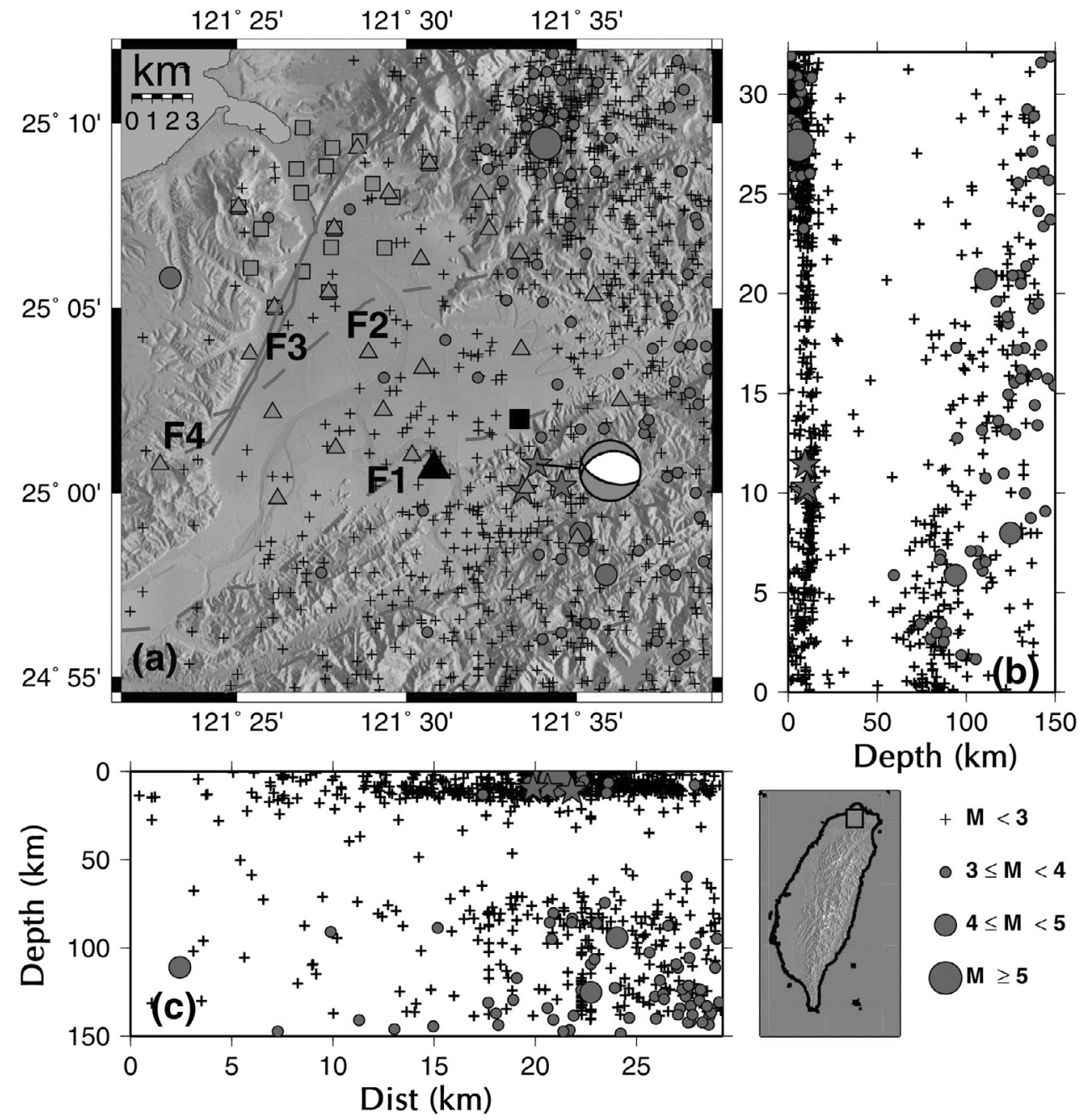

Fig. 1. (a) Seismicity in the Taipei area recorded by the TTSN and CWBSN from 1973 to March 2006. Three felt earthquakes (stars) occurred near the eastern area of the Taipei basin, about $3 \mathrm{~km}$ to the south of Taipei 101 (large square) then the tallest building in the world. The large triangle denotes the downhole seismic station at YH. The map also shows focal mechanism of the 23 October 2004 earthquake determined by Lin (2005). The dashed and solid lines mark the Taipei fault (F1), the Kangjiao fault (F2), the Shanchiao fault (F3) and the Hsinchuang fault (F4), respectively. Temporary broadband seismic stations noted along the northern segment of the Shanchiao fault from June 2004 to June 2005 (squares), and the rearrangement of stations after June 2005 to cover the whole Taipei basin (triangles). Depth cross-sections of hypocenters: (b) for the NS direction and (c) for the EW direction.

felt earthquakes $\left(\mathrm{M}_{\mathrm{L}}=3.8,3.2\right.$, and 3.7) occurred near the eastern part of the basin, about $3 \mathrm{~km}$ to the south of Taipei 101 then tallest building in the world. Lin (2005) suggested that the felt earthquakes were triggered by the load of the massive skyscraper (Taipei 101) and an active blind normal fault was located just beneath the building. However, the locations of the three events and their correlation to the possible blind normal fault need a further study.

Due to the importance of TMA for Taiwan, it is necessary to determine if the seismic activity is associated with the three known faults or others existing beneath the Taipei basin. In this study, local earthquakes recorded by a temporary broadband seismic array during June 2004 - June 2005 and collected over the last 34 years were analyzed to construct the seismicity pattern and focal mechanisms of larger- sized events. From the results, we will study the correlation between seismicity and faults and explore the possibility of the existence of blind active faults.

\section{GEOLOGICAL SETTINGS}

The Taipei basin is located at the northern tip of the Taiwan Mountain belt. The basin is bordered by the Western Foothills to the south and east, the Tatun volcanoes to the north, and the Linkou Tableland to the west (Figs. 1 and 2). There are three major thrust faults striking in the NESW direction across the Taipei basin (Ho 1986). These contractional structures are formed by the northwest-directed tectonic stress of collisional orogeny (Ho 1974; Angelier et al. 1986). The tectonic pattern in northern Taiwan has been 

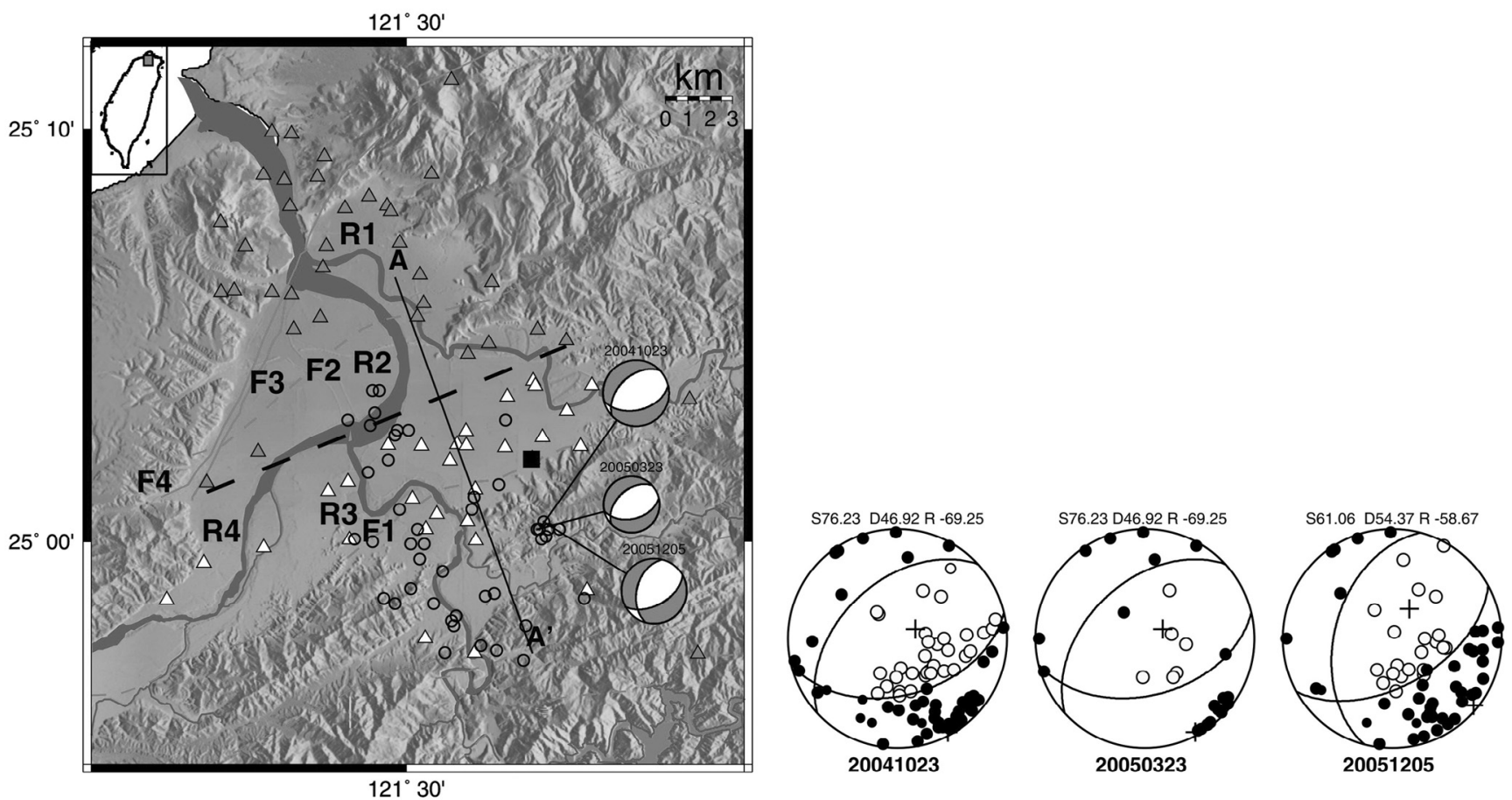

Fig. 2. Epicentral distribution of the relocated earthquakes (circles) recorded by the temporary and permanent seismic network from 1973 to March 2006. Solid and blank triangles denote the compressional and dilatational polarities of the first motions for the 23 October 2004 earthquake, respectively. The thick dashed line denotes the proposed fault trace from this study. Note that the proposed fault line is clearly separated by the opposite polarities of the first motions and lies along the river channel. Included also are the lower-hemisphere, first-motion focal mechanisms of the three felt earthquakes. Four main rivers across the Taipei basin: the Keelung (R1), Tanshui (R2), Hsintien (R3) and Tahan rivers (R4). WF, TV and LT denote the Western Foothills, the Tatun volcanoes and the Linkou Tableland, respectively.

changed from contractional to extensional since the late Quaternary (Teng 1996; Teng et. al. 2001). The Hsinchuang thrust fault (Wu 1965) in the westernmost area of the basin altered its sense of movement and was transformed into the Shanchiao normal fault, which caused subsidence and sedimentation of the Taipei basin. Under the sponsor of the Central Geological Survey (CGS 1999), much effort has been made to investigating the subsurface geology and engineering environment of the Taipei basin since 1991.

The Taipei basin is a triangular-shaped alluvium filled with Quaternary unconsolidated sediments overlying a Tertiary basement. The sediments thicken northwestward from a thin basin margin in the southeast to about $700 \mathrm{~m}$ in the northwest corner of the basin (Lin 2001). Low seismicity, faulting beneath thick unconsolidated sediments and very low slip rates on faults in the Taipei basin make it difficult to identify surface fault traces. There are three major thrust faults striking in the NE-SW direction across the basin (Ho 1986). From east to west, they include the Taipei fault (F1), Kangjiao fault (F2), and Hsinchuang fault (F4). The Shanchiao fault (F3) is believed to be an active normal fault. The geometry and surface trace of the Shanchiao fault were delineated by using shallow seismic reflection (Wang and Sun 1999; Shih et al. 2004; Wang et al. 2004). The relatively flat deposits of the topmost layers on the seismic profile is consistent with the interpretation of borehole data, that is, the Shanchiao fault has been active but might be quiet over the past 10000 years (Lin 2001). Radiocarbon dating from drilled cores suggests that three prehistoric earthquakes ruptured the Shanchiao fault in the past 11000 years, and the latest event occurred around 8400 years ago (Huang et al. 2003).

\section{DATA}

From 1973 to 1992, the Taiwan Telemetered Seismographic Network (TTSN) (Wang 1989) was operated by the Institute of Earth Sciences (IES), Academia Sinica. This network consisted of 25 stations and each was equipped with a vertical high-gain and analog velocity seismometer. Since 1991, the Taiwan Seismic Network (TSN) (Shin 1992) operated by the Central Weather Bureau (CWB) has been upgraded from the CWB's old seismic network, and many new stations have also been constructed. This network is called the CWB's Seismic Network (CWBSN). In 1992, the TTSN was merged into the TSN to form the CWBSN. At present, the CWBSN is composed of 71 stations, each equipped with three-component digital velocity seismometers (Wu et al. 2008). The seismograms are recorded in both high- and low-gain forms by the network. Hence, this network pro- 
vides high-quality digital earthquake data. Earthquakes in the TMA recorded by the TTSN from 1973 to 1990 and by the CWBSN from 1991 to March 2006 were used in this study.

To determine if the Shanchiao fault extends northeastward to the Tatun volcanic area, a dense broadband seismic array (see Fig. 1) sponsored by the CGS was deployed along the northern segment of the Shanchiao fault to monitor seismic activity from June 2004 to June 2005. The temporary seismic array consisted of 17 stations equipped with broadband sensors with a frequency range from 0.0083 to $50 \mathrm{~Hz}$ and GPS timing systems. Continuous recording was 100 samples per second. The sensors were buried at a depth of about 1 meter to suppress man-made noises. During one year of operation, a total of 318 local events were recorded. Earthquakes were located preliminarily using the computer program HYPOELIPSE (Lahr 1989) based on a velocity model for northwestern Taiwan (Chen 1995). Most events are located in northeastern Taiwan, and only 40 events in the Tatun volcanic area and to the southeast of the basin. No earthquake was located within the small seismic array. Nevertheless, two felt earthquakes $\left(\mathrm{M}_{\mathrm{L}}=3.7\right.$ and 3.2) occurred at a depth of about $9 \mathrm{~km}$ near the eastern Taipei basin on 23 October 2004 and 23 March 2005. These events were located about $3 \mathrm{~km}$ to the south of Taipei 101 .

In June 2005 , the temporary seismic array was reformed and expanded to 23 stations covering the whole of the Taipei basin (Fig. 1). A felt earthquake $\left(\mathrm{M}_{\mathrm{L}}=3.7\right)$ occurred very close to the previous two felt earthquakes on 5 December 2005. The shallow events within and near the Taipei basin recorded by the temporary broadband seismic array and collected over the last 34 years were relocated using a joint hypocentral determination (JHD) technique (Pujol 1988).

\section{SEISMICITY IN THE TAIPEI BASIN}

Figure 1 shows the earthquakes located by the TTSN and CWBSN. Most earthquakes were located to the north and southeast of the Taipei basin. In addition to shallow earthquakes of depths less than $15 \mathrm{~km}$, the intermediate depth earthquakes from 70 to $150 \mathrm{~km}$ were associated with the northwestward subduction of the Philippine Sea plate beneath the Eurasian plate. An M5 earthquake occurred at a depth of $5.3 \mathrm{~km}$ in the Tatun volcanic area in 1988. This has been the largest event in the TMA since 1973. Most earthquakes with $\mathrm{M} \geq 3$ were located underneath the Tatun volcanic area, to the southeast of the Taipei basin, and inside the subduction zone. However, no shallow earthquake with $M \geq 3$ was located in the Taipei basin.

To examine the correlation between seismic activity and the recognized active faults, the collected shallow earthquakes with depths less than $15 \mathrm{~km}$ were relocated using the JHD technique (Pujol 1988). The velocity model which was inferred by Chen (1995) from P- and S-wave arrival times of local earthquakes beneath northwestern Taiwan was used. The JHD technique is relatively insensitive to the choice of velocity model and station-correction terms will approximately compensate for the deviations of the implemented velocity model from the real earth structure. Determination of earthquake hypocenters using the JHD technique is an iteration process, with an iteration consisting of two steps. Station corrections are determined in the first step of iteration with current earthquake hypocenters and origin times. In the second step, earthquake hypocenters and origin times are determined with a least squares method using station corrections determined in the first step. In the next iteration, earthquake parameters and station corrections determined in the previous iteration are used as initial parameters. For one time of iteration, in general, the root-mean-square (RMS) residual of the events decreases. Usually, convergence is achieved in a few iterations. The JHD technique has been successfully used to detect lateral velocity variations and to improve relative earthquake locations in the Taiwan area (Chen et al. 1999, 2002; Kim et al. 2005b) and other various tectonic regions (e.g., Pujol 1995).

In all, 51 events recorded by more than 4 stations with depths less than $15 \mathrm{~km}$ and good azimuth coverage were selected from the CWB earthquake catalog and the data recorded by the temporary broadband seismic array. The phase data include $463 \mathrm{P}$-wave and $284 \mathrm{~S}$-wave arrival times. In earthquake location, three events were rejected due to large arrival time residuals and/or large values of condition number (the ratio of the largest singular value to the smallest one). The average RMS residual decreased from 0.93 to 0.2 seconds after six iterations. The station corrections vary from -0.78 to 1.21 seconds and -1.73 to $1.21 \mathrm{sec}-$ onds for the $\mathrm{P}$ - and $\mathrm{S}$-wave, respectively. This leads to three results: (1) The relocated earthquakes are more clustered for the southeastward dipping hypocenters; (2) The epicenters of the selected events were shifted an average of $1.3 \mathrm{~km}$ toward the southwest of the initial hypocenters; and (3) The focal depths were decreased by $\sim 1.2 \mathrm{~km}$.

The relocated events in the Taipei basin are depicted in Fig. 2. Obviously, the earthquakes are mostly located in the southeastern part of the basin. There is no earthquake near the Shanchiao fault. Most events are located to the southeast of the Kangjiao fault. Fault-plane solutions of three felt earthquakes were determined using the P-wave first motions. A grid-search algorithm (Snoke et al. 1984) is used to infer all possible mechanisms by fitting the $\mathrm{P}$-wave polarity of an earthquake. The source-station take-off angles and azimuths are calculated from the JHD relocation. The focal mechanisms for the three felt earthquakes show predominantly normal faulting with two nodal planes striking northeast (Fig. 2). The distribution of polarities for the 23 October 2004 earthquake is also shown in Fig. 2. The three felt events occurred very close to one another in space and 
have similar focal-plane solutions leading to a similar distribution of polarities.

A depth cross-section (AA') of hypocenters (see Figs. 2 and 3), perpendicular to the average strike of the nodal planes of the three felt earthquakes clearly reveals southeastward dipping of hypocenters extending to a depth of $\sim 14 \mathrm{~km}$. This southeastward dipping seismic zone is consistent with the dip angles of the fault-plane solutions. The three felt earthquakes occurred in the seismic fault zone at a depth of $\sim 9 \mathrm{~km}$. The surface projection of the southeast dipping seismic zone is located in the middle of the basin, about $5 \mathrm{~km}$ southeast of the Kangjiao fault. The surface fault line inferred from the seismicity pattern and focal mechanisms clearly separates the opposite polarities of the first motions for the 23 October 2004 earthquake (Fig. 2).

\section{DISCUSSION}

As shown in Fig. 2, most shallow events were located about $5 \mathrm{~km}$ to the southeast of the Kangjiao fault. The hypocentral distribution of relocated earthquakes suggests the possible existence of a blind normal fault as shown by a dashed line in Fig. 3. The surface trace, which is shown by a dashed line in Fig. 2, is located in the middle of the basin. However, surface ruptures associated with this fault were not observed. The fault might lie beneath thick unconsolidated sediments in the study area. Figures 2 and 3 show that only four events, with depths of $8-11 \mathrm{~km}$, were located to the northwest of the blind fault. It is not easy to determine if these four events are associated with the Kangjiao fault or other faults.

During the deployment of a temporary broadband seismic array, three felt earthquakes occurred beneath the eastern part of the Taipei basin, about $3 \mathrm{~km}$ to the south of Taipei 101. From the CWBSN catalogue, the hypocenters of the three felt earthquakes were apart about $1.8 \mathrm{~km}$ from one another (Fig. 1). The JHD relocated earthquakes form a small cluster with a dimension of $\sim 0.5 \mathrm{~km}$ across at a depth of about $9 \mathrm{~km}$. Figure 4 shows an example of three-component seismograms of the three felt earthquakes recorded by a nearby downhole seismic station at $\mathrm{YH}$ (see Fig. 1) after bandpass filtration $(1-10 \mathrm{~Hz})$ and alignment of their S-wave arrivals. The first two events show almost the same P-wave arrivals, while the P-wave arrival of the third event shows about $0.08 \mathrm{sec}$ preceding those of the other two. The travel-time differences confirm reliability of earthquake relocation. The three seismograms show remarkable similarities suggesting that the three events occurred very close to one another in space and were the result of ruptures on a same fault. The three felt earthquakes were located almost on the proposed blind normal fault. The strikes and dips of focal mechanisms of the three events are consistent with those of the proposed blind normal fault (Fig. 2). In addition, the related surface fault trace clearly separates the opposite polarities of the first motions for the 23 October 2004 earthquake which is closely associated with the surface trace of the proposed blind fault rather than with the Kangjiao or Taipei fault. Hence, focal mechanisms of the three felt earthquakes suggest the existence of the proposed blind normal fault.

Based on the CWB's catalog, Lin (2005) assumed that several felt earthquakes were located in an active blind normal fault striking in the N-W direction and beneath Taipei 101. However, his assumption cannot properly explain the southeastward dipping seismic fault zone and the distribution of polarities of the first motions of the 23 October 2004 earthquake.

The surface trace of the proposed blind normal fault is located in the middle of the basin along the NE-SW direction and lies along the river channel of the lower reach of the Tahan River (Fig. 2). A further study is necessary to shed light on the evolution of the river system in response to faulting in the Taipei basin through a detailed geological survey. In addition, high-resolution seismic reflection experiments must be made in the study area to map the detailed sub-surface velocity and geological structures of the basin and basement.

\section{CONCLUSIONS}

Well-relocated earthquakes recorded by a temporary broadband seismic array during June 2004 - June 2005 and collected by the TTSN and CWBSN over the last 34 years in the Taipei basin suggest the possible existence of a blind

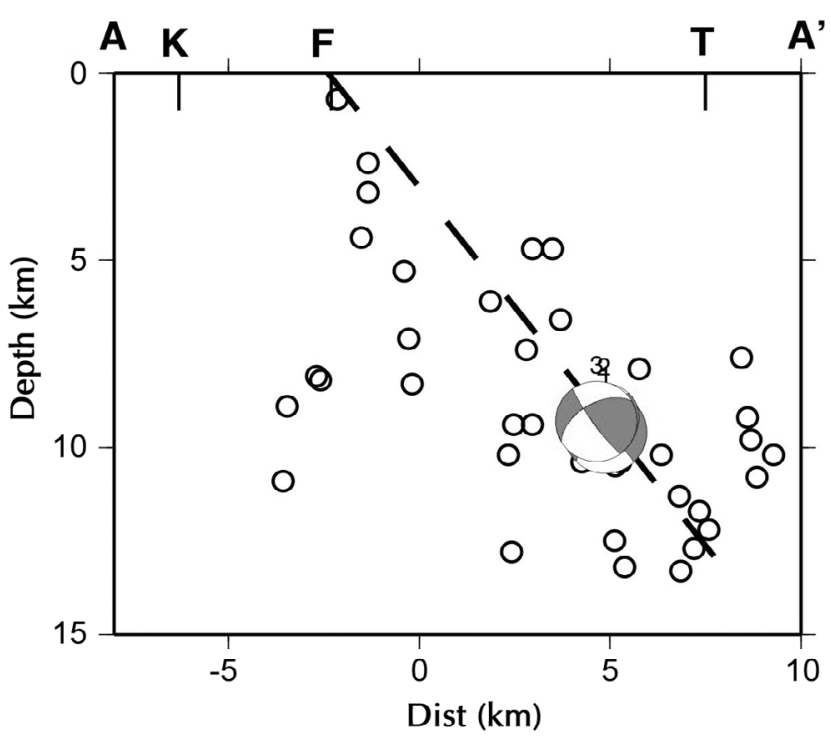

Fig. 3. Depth cross-section of the earthquakes along line AA' shown in Fig. 2 and cross-sectional view of focal mechanisms for the three felt earthquakes. The dashed line depicts the fault geometry inferred from both the earthquake distribution and focal mechanisms of felt earthquakes. F1 and F2 denote the Taipei and Kangiiao faults, respectively. 


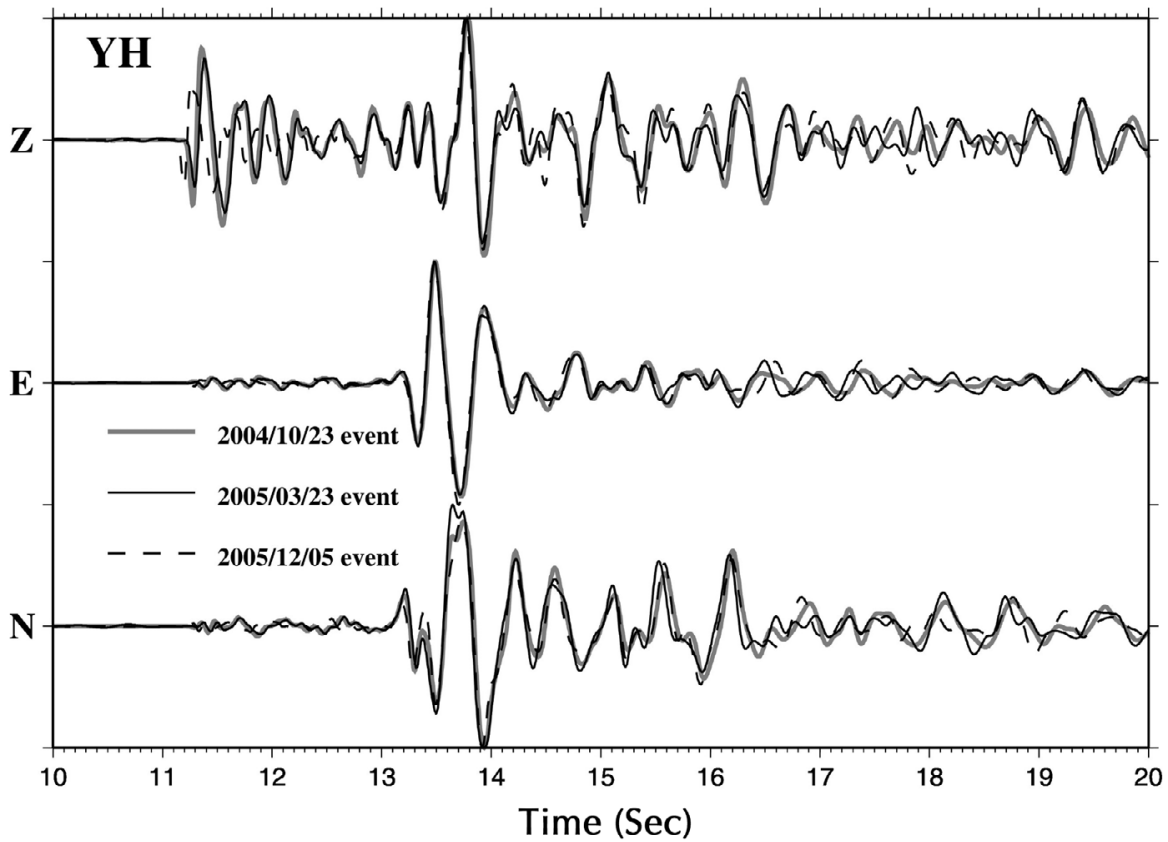

Fig. 4. Three-component seismograms of the three felt earthquakes recorded by the nearby downhole seismic station (YH) after bandpass filter (1 $10 \mathrm{~Hz}$ ) and alignment of their S-wave arrivals. The three events show high waveform similarity throughout the entire seismograms, indicating that spatially they occurred very close to each other.

normal fault dipping to the southeast. Three current felt earthquakes with normal faulting are located at depths of $\sim 9 \mathrm{~km}$ on this proposed fault. The surface fault trace inferred from the seismicity patterns and focal mechanisms lies along the channel of the Tahan River in the middle of the basin. This proposed fault will help seismologists to better assess seismic hazards in the area.

Acknowledgements The authors thank Prof. L. S. Teng (National Taiwan University) for valuable discussion. Critical review and comments by Dr. Yih-Min Wu and two anonymous reviewers are highly appreciated. The strongmotion and phase data are provided by the Central Weather Bureau. This study was supported by the Central Geological Survey, Ministry of Economic Affairs, under grant CGS965226902000-01-02, Academia Sinica, No. AS-94-TP-A08, the Korea Meteorological Administration Research and Development Program under Grant CATER2006-5101 (K. H. Kim), and the National Science Council, ROC, under grant NSC 96-2119-M-001-011, with TEC Contribution Number 00062.

\section{REFERENCES}

Angelier, J., E. Barrier, and H. T. Chu, 1986: Plate collision and paleostress trajectories in a fold-thrust belt: The foothills of Taiwan. Tectonophysics, 125, 161-178, doi: 10.1016/0040-1951(86)90012-0. [Link]

CGS (Central Geological Survey), 1999: Subsurface Ge- ology and Engineering Environment of Taipei Basin. Special Publ., 11, Central Geological Survey, MOEA, Taipei, Taiwan, ROC, 406 pp.

Chen, K. C., 2003: Strong ground motion and damage in the Taipei basin from the Moho reflected seismic waves during the March 31, 2002, Hualien, Taiwan earthquake. Geophys. Res. Lett., 30, 1551, doi: 10.1029/2003GL017193. [Link]

Chen, K. C., 2005: Temporal-spatial distributions of earthquakes. In: Wang et al. (Eds.), The 921 Chi-Chi Great Earthquake, Office of Inter-Ministry S\&T Program for Earthquake and Active-fault Research, NSC, 263-277. (in Chinese)

Chen, K. C. and J. H. Wang, 1988: A study on aftershocks and local mechanisms of two 1986 earthquakes in Hualien, Taiwan. Proc. Geol. Soc. China, 31, 65-72.

Chen, K. C., B. S. Huang, K. L. Wen, H. C. Chiu, Y. T. Yeh, S. N. Cheng, H. Y. Peng, T. M. Chang, T. C. Shin, R. C. Shih, and C. R. Lin, 1999: A study of aftershocks of the 17 July 1998 Ruey-Li, Chiayi earthquake. Terr. Atmos. Ocean. Sci., 10, 605-618.

Chen, K. C., B. S. Huang, J. H. Wang, and H. Y. Yen, 2002: Conjugate thrust faulting associated with the 1999 Chi-Chi, Taiwan, earthquake sequence. Geophys. Res. Lett., 29, 1277, doi: 10.1029/2001GL014250. [Link]

Chen, K. J. and Y. H. Yeh, 1991: Gravity and microearthquake studies in the Chinshan-Tanshui area, northern Taiwan. Terr. Atmos. Ocean. Sci., 2, 35-50.

Chen, K. J., Y. H. Yeh, H. Y. Yen, and C. H. Lin, 1995: 
Seismological studies in the Chinshan fault area. $J$. Geol. Soc. China, 38, 335-352.

Chen, Y. L., 1995: Three-dimensional velocity structure and kinematic analysis in the Taiwan area. Master Thesis, National Central University, Jhongli, Taiwan, ROC, 172 pp. (in Chinese)

Ho, C. S., 1974: The Taipei fault and related structural features in northern Taiwan. Proc. Geol. Soc. China, 17, 95-109.

Ho, C. S., 1986: An Introduction to the Geology of Taiwan: Explanatory Text of the Geologic Map of Taiwan. Central Geological Survey, MOEA, Taipei, Taiwan, ROC, 163 pp. (in Chinese)

Hsu, M. T., 1961: Seismicity of Taiwan (Formosa). Bull. Earthq. Res. Inst., Tokyo Univ., 39, 831-847.

Hsu, M. T., 1983: Estimation of earthquake magnitudes and seismic intensities of destructive earthquakes in the Ming and Ching Eras. Meteorol. Bull. CWB, 29, 1-18. (in Chinese)

Huang, S. Y., C. M. Rubin, Y. G. Chen, H. C. Liu, and C. L. Chiu, 2003: Prehistoric earthquakes along the Shanchiao fault, Taipei Basin, Northern Taiwan. Eos, Trans., AGU, 84, Fall Meeting, Suppl., Abstract, San Francisco, CA.

Kim, K. H., C. H. Chang, K. F. Ma, J. M. Chiu, and K. C. Chen, 2005a: Modern seismic observations in the Tatun volcano region of northern Taiwan: Seismic/volcanic hazard adjacent to the Taipei Metropolitan area. Terr. Atmos. Ocean. Sci., 16, 579-594.

Kim, K. H., J. M. Chiu, J. Pujol, and K. C. Chen, 2005b: Earthquake relocations, fault zone geometry and constraints on lateral velocity variations using the joint hypocenter determination method in the Taiwan area. Earth Planets Space, 57, 809-823.

Konstantinou, K. I., C. H. Lin, and W. T. Liang, 2007: Seismicity characteristics of a potentially active Quaternary volcano: The Tatun Volcano Group, northern Taiwan. J. Volcanol. Geotherm. Res., 160, 300-318, doi: 10.1016/j.jvolgeores.2006.09.009. [Link]

Lahr, J. C., 1989: HYPOELLIPSE/version 2.00: A computer program for determining local earthquake hypocentral parameters, magnitude, and first motion pattern. US Geological Survey Open-File Report 89-116.

Lin, C. C., 2001: Geology environment of Taipei metropolis. Symposium on the Geological Hazards of Taipei Metropolis, 1-19. (in Chinese)

Lin, C. H., 2002: Active continental subduction and crustal exhumation: The Taiwan orogeny. Terr. Nova, 14, 281-287.

Lin, C. H., 2005: Seismicity increase after the construction of the world's tallest building: An active blind fault beneath the Taipei 101. Geophys. Res. Lett., 32, L22313, do: 10.1029/2005GL024223. [Link]

Pujol, J., 1988: Comments on the joint determination of hy- pocenters and station corrections. Bull. Seismol. Soc. Am., 78, 1179-1189.

Pujol, J., 1995: Application of the JHD technique to the Loma Prieta, California, mainshock-aftershock sequence and implications for earthquake location. Bull. Seismol. Soc. Am., 85, 129-150.

Seno, T., 1977: The instantaneous rotation vector of the Philippine sea plate relative to the Eurasian plate. Tectonophysics, 42, 209-226, doi: 10.1016/0040-1951(77) 90168-8. [Link]

Shih, R. C., Y. H. Chan, and H. C. Liu, 2004: Shallow seismic reflection surveys of the Shanchiao fault in the Guandu plain. Spec. Publ. Cent. Geol. Surv., 15, 1-11. (in Chinese)

Shin, T. C., 1992: Some implications of Taiwan tectonic features from the data collected by the Central Weather Bureau Seismic Network. Meteorol. Bull. CWB, 38, 23-48. (in Chinese)

Shin, T. C. and T. L. Teng, 2001: An overview of the 1999 Chi-Chi, Taiwan, earthquake, Bull. Seismol. Soc. Am., 91, 895-913, doi: 10.1785/0120000738. [Link]

Snoke, J. A., J. W. Munsey, A. G. Teague, and G. A. Bollinger, 1984: A program for focal mechanism determination by combined use of polarity and SV-P amplitude ratio data. Earthq. Notes, 55, 15.

Tan, K., 1939: Geological consideration on the Taihoku Basin. In: Commemoration of Prof. H. Yabe's $60^{\text {th }}$ Birthday, Jubilee Publication, 1, 371-380. (in Japanese)

Teng, L. S., 1996: Extensional collapse of the northern Taiwan mountain belt. Geology, 24, 949-952, doi: 10.11 30/0091-7613(1996)024<0949:ECOTNT>2.3.CO;2. [Link]

Teng, L. S., C. T. Lee, C. H. Peng, J. J. Chu, and W. F. Chen, 2001: Origin and geological evolution of the Taipei basin, northern Taiwan. West. Pac. Earth Sci., 1, 115-142.

Tsai, Y. B., H. B. Liaw, and C. C. Feng, 1973: A study of microearthquakes in the Tatun volcanic region. Ann. Rept. Inst. Phys., Acad. Sin., 239-250.

Tsai, Y. B., T. L. Teng, J. M. Chiu, and H. L. Liu, 1977: Tectonic implications of the seismicity in the Taiwan region. Mem. Geol. Soc. China, 2, 13-41.

Wang, C. Y. and C. T. Sun, 1999: Interpretation of seismic stratigraphy in the Taipei basin. Special Publ., 11, Central Geological Survey MOEA, Taipei, Taiwan, ROC, 273-292.

Wang, C. Y., Y. H. Lee, M. L. Ger, and Y. L. Chen, 2004: Investigating subsurface structures and $\mathrm{P}$ - and $\mathrm{S}$-wave velocities in the Taipei basin. Terr. Atmos. Ocean. Sci., 15, 609-627.

Wang, J. H., 1988: $b$ values of shallow earthquakes in Taiwan. Bull. Seismol. Soc. Am., 78, 1243-1254.

Wang, J. H., 1989: The Taiwan Telemetered Seismographic Network. Phys. Earth Planet. Inter., 58, 9-18, doi: 
10.1016/0031-9201(89)90090-3. [Link]

Wang, J. H., 1998: Studies of earthquake seismology in Taiwan during the 1897-1996 period. J. Geol. Soc. China, 41, 291-336.

Wang, J. H., Y. B. Tsai, and K. C. Chen, 1983: Some aspects of seismicity in Taiwan region. Bull. Inst. Earth Sci., Acad. Sin., 3, 87-104.

Wang, J. H., M. W. Huang, and W. G. Huang: 2006, Aspects of $\mathrm{M} \geq 4$ earthquakes in the Taipei metropolitan area. West. Pac. Earth Sci., 6, 169-190.
Wu, F. T., 1965: Subsurface geology of the Hsinchuang structure in the Taipei Basin. Petrol. Geol. Taiwan, 4, 271-282.

Wu, F. T., 1978: Recent tectonics of Taiwan. J. Phys. Earth, 2 (Suppl.), S265-S299.

Wu, Y. M., C. H. Chang, L. Zhao, T. L. Teng, and M. Nakamura, 2008: A comprehensive relocation of earthquakes in Taiwan from 1991 to 2005. Bull. Seismol. Soc. Am., 98, 1471-1481, doi: 10.1785/0120070166. [Link] 